\title{
Land Use Development of Vineyards in Goriška Brda, Slovenia
}

\author{
Alenka FIKFAK ${ }^{1}$, Velibor SPALEVIC ${ }^{2 *}$, Saja KOSANOVIC ${ }^{3}$, \\ Svetislav G. POPOVIC ${ }^{4}$, Mladen DJUROVIC ${ }^{4}$, Miha KONJAR ${ }^{1}$
}

\author{
${ }^{1}$ University of Ljubljana, Faculty of Architecture, Zoisova cesta 12, 1000 Ljubljana, \\ Slovenia; alenka.fikfak@fa.uni-lj.si; miha.konjar@fa.uni-lj.si \\ ${ }^{2}$ University of Montenegro, Geography Department of the Faculty of Philosophy, D. Bojovica, 81400 Niksic, \\ Montenegro; velibor.spalevic@gmail.com (*corresponding author) \\ ${ }^{3}$ University of Pristina settled in Kosovska Mitrovica, Faculty of Technical Sciences, Department of Architecture, \\ K. Milosa 7, 38220 Kosovska Mitrovica, Serbia; saja.kosanovic@pr.ac.rs \\ ${ }^{4}$ University of Montenegro, Faculty of Architecture, Dzordza Vasingtona Street bb, 81000 Podgorica, \\ Montenegro;svetislav@ac.me; mladen.djurovic.ucg@gmail.com
}

\begin{abstract}
Land development analyses play a fundamental role in understanding how land use change shapes the land, depending on continuously changing social, economic, and environmental factors that reflect the interests in space. It is especially important to follow land use changes in rural areas due to their role in food security, environmental hazards, cultural landscape preservation, etc. Continuous analyses and monitoring of land use changes allow for the identification and prevention of negative trends in land use (over intensification, land fragmentation, etc.) that might affect biodiversity, change physical and chemical properties of soil, causing soil degradation, change the spatial balance, stability and natural equilibrium in the rural area. The use of the cross-tabulation matrix methodology was suggested for land use change analyses. The methodology, when the cross-tabulation matrix elements are correctly interpreted, allows us to gain as much insight as possible in the process of land use change. This approach enabled a detailed analysis of vineyards in Goriška brda, Slovenia. It was found that the existing methodology fails to analyse the location of change. For this reason, additional analyses of spatial distribution of change and of the locations where changes in space occur were suggested. The study demonstrated that the land use category of vineyards changes systematically, although seemingly randomly. By comparing land use categories over several time periods, the study determined that the size and speed of change varied across different time intervals. The identified land use changes were assessed in the context of their high pressure on agricultural land. The results of the analyses showed different trends shaping the typical agrarian landscape in Goriška brda.
\end{abstract}

Keywords: land use changes, rural areas, cross-tabulation matrix, vineyards, Goriška brda

\section{Introduction}

The changes in the production system, based on coexistence and complementarity of agrarian and non-agrarian functions, have transformed the transitional patterns of the built environment (Amato et al., 2017; Antrop, 1993). Each individual, whether a farmer or not, is increasingly more attentive to the environment and its exploitation for improving our culture of living, which is directly or indirectly connected with everything that affects humankind, its development, changing, and adapting to the current transformation processes in cultural, natural, and agricultural landscapes (Fikfak, 2008; Marques et al., 2015; Sastre et al., 2016). Nowadays, we witness various processes, such as rural depopulation and population aging, demography changes, functional transformation (the city $=$ a consumption area), which have been, over the last 20 years, paired with problems of discontinuation and abandonment of agriculture due to the lack of production competitiveness in the regions defined as areas with restricted factors for agriculture (Fikfak et al., 2015). Landuse and land-cover change profoundly affect human wellbeing and, therefore, have become a major topic for society (Bieling et al., 2013). Current land development patterns have been strongly influenced by past development patterns, 
612

agricultural suitability, transportation, natural amenities, and economic and recreational characteristics (Gude $e t$ al., 2006). In the past few decades, land-use and land-cover change, abbreviated as "land change", has become a major topic for society in various contexts, but particularly as connected to the issue of sustainability (Turner et al., 2007). Intensification of land use and the inevitable expansion of land that is allocated to agriculture will combine to determine environmental outcomes (Sayer et al., 2013). The changing of land use also affects the transformation of the built environment, which is in rural areas increasingly directed toward local, contemporary, self-sufficient communities, where spatial balance, stability, and biodiversity provide the basis for sustainable development in equilibrium with environmental characteristics (Fikfak, 2008). However, such settlement models are burdened with land fragmentation, precluding sustainable land use with their ownership structure. The presence of numerous undersized plots of farmland leads to inefficient use of the technique, low efficiency in land use, the impossibility of applying modern methods in agriculture (Borisov, 2015). Agricultural functionality is to a great extent negatively affected by fragmentation, which results in a "scattering" of the farm elements across the land (Mazzocchi et al., 2013). Land use change and agricultural management (e.g. tillage, pesticide and fertilizer applications) affect soil biodiversity, changing physical and chemical properties of soil (GarcíaDíaz et al., 2017; Pampulha and Oliveira, 2006; Jangid et al., 2008; Castañeda and Barbosa, 2016).

Vineyards are notably one of the land uses, in particular in Mediterranean environments, in which high erosion rates are being recorded (Kosmas et al., 1997; Prosdocimi et al., 2016). With the decrease of agricultural land use in Slovenia due to natural, social, and economic factors, the amount of material lost to erosion has decreased correspondingly in the last few decades (Komac and Zorn, 2005). The occurrence of extreme rainfall events, soil characteristics and, in some cases, steep slopes contribute to soil degradation (Rodrigo Comino et al., 2016). Goriška brda is no exception. That is why, in Mediterranean landscapes cultivated terraces have been a significant feature, shaping the appearance of the landscape for centuries (Kladnik et al., 2016).

Facing these challenges, the aim of this paper was to articulate the analyses of land use changes and development, statistical and spatial data and density-level investigations of vineyard areas as a land use category in Goriška brda, Slovenia; including land use data available (from 2002 to 2015) and the cross-tabulation matrix methodology.

\section{Land use development and biodiversity}

Land use development studies are becoming more and more important in everyday life as we are starting to realize how limited and fragile the space that we occupy is. While the use of space was once investigated separately for each sector and for specific needs, now it is interdisciplinary and the need to study and understand the entire system of spatial development comes to the fore, which is reflected in land use and its changes. In land use and land use change analyses it is important to differentiate between planned land use, as one of the main instruments for the implementation of local spatial plans and the actual use of land, which is understood as a spatial reflection of physical characteristics, socio-economic characteristics, and ecological awareness (EU-LUPA, 2012). Actual land use reflects human activities over time, while showing the current development level and spatial conditions. As such actual land use was the main focus of the research presented in this paper.

Land use may vary in nature and intensity according to both the purpose it serves (food production, recreation, etc.) and to the biophysical characteristics of the land itself (Verheye, 2009). Land use changes are in general regarded as a dynamic process reflecting complex relationships between natural, social, economic, and historical factors. These natural factors include natural conditions and terrain diversity (Rikanovič, 2003), while social, economic, and historical conditions include settlement and economic conditions, as well as land ownership relationships (Kladnik and Gabrovec, 1998). Mlakar (2009) even states that the environment and space are inherently characterised by the unpredictability of change that is far too complex to be comprehended entirely. In general, we distinguish between three major types of changes: land use conversions (changes from one type to another), land use modifications (alterations in structure and/or function without a wholesale change from one type to another) and the maintenance of the land in its current conditions against agents of change (Briassoulis, 2000). In the case of agricultural land use, the changes may include intensification, extensification, and marginalization of the land (Verheye, 2009).

Another important area of studies into land use and its changes is land use intensity, which is particularly relevant in agriculture. The land use intensity relates to the magnitude of human interactions caused by the activities taking place on a given area of land; and therefore, on the intensity with which land is manipulated (EU-LUPA, 2012). It was proven that land use intensity in agriculture is not affected only by changes in agricultural policy, but also the changing conditions on the market, dictated by demand (IAMO, 2006; Kahan, 2013). At the same time land use intensity in agriculture strongly affects the functioning of the ecosystem, particularly (agro)biodiversity (Matson et al., 1997; Stoate et al., 2001; Reidsma et al., 2006; Kleijn et al., 2009). The relationship between low agricultural intensity and high biodiversity is the basis for the high natural value of agricultural land, as stressed, at the European level, by the European Environmental Agency (EEA, 2004).

\section{Materials and Methods}

\section{Study area}

Goriška brda (area of $72 \mathrm{~km}^{2}$ ), a part of the North Primorska region in western Slovenia (Fig. 1), is an independent, geographically and spatially defined unit with 5,664 residents (79 inhabitants $/ \mathrm{km}^{2}$ ) (SORS, 2016). This range of hilly ridges between Italy to the east and the Soča Valley to the west has an average elevation of $233 \mathrm{~m}$, with Korada $(811 \mathrm{~m})$ as the highest hill. The terraced, cultivated areas are located at a height of $55 \mathrm{~m}$ up to $586 \mathrm{~m}$ (Kladnik, 1998). The landscape is characterised by soft flysch 


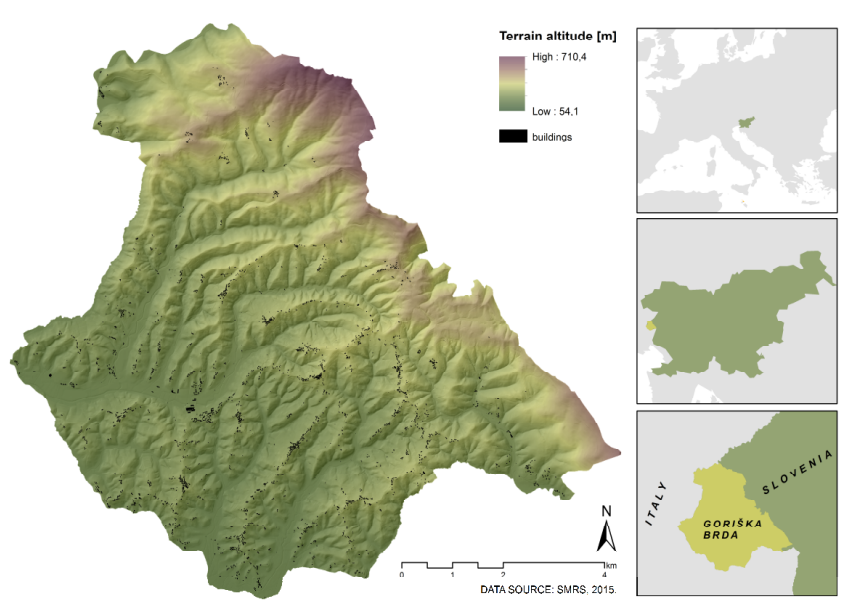

Fig. 1. Goriška brda, Slovenia. The study area

indented with streams, which created a distinct landscape of hills with north-south stretching ridges (three main strike lines oriented NNE-SSW) and with shorter transversal ridges (Pavlovec, 1966). The ridges are mostly sedimentary flysch rock composed of alternating layers of sandstone, marl, and carbonate turbidite, as well as limestone or calcarenite ranging from a few centimetres up to half a metre thick (Zorn and Komac, 2009).

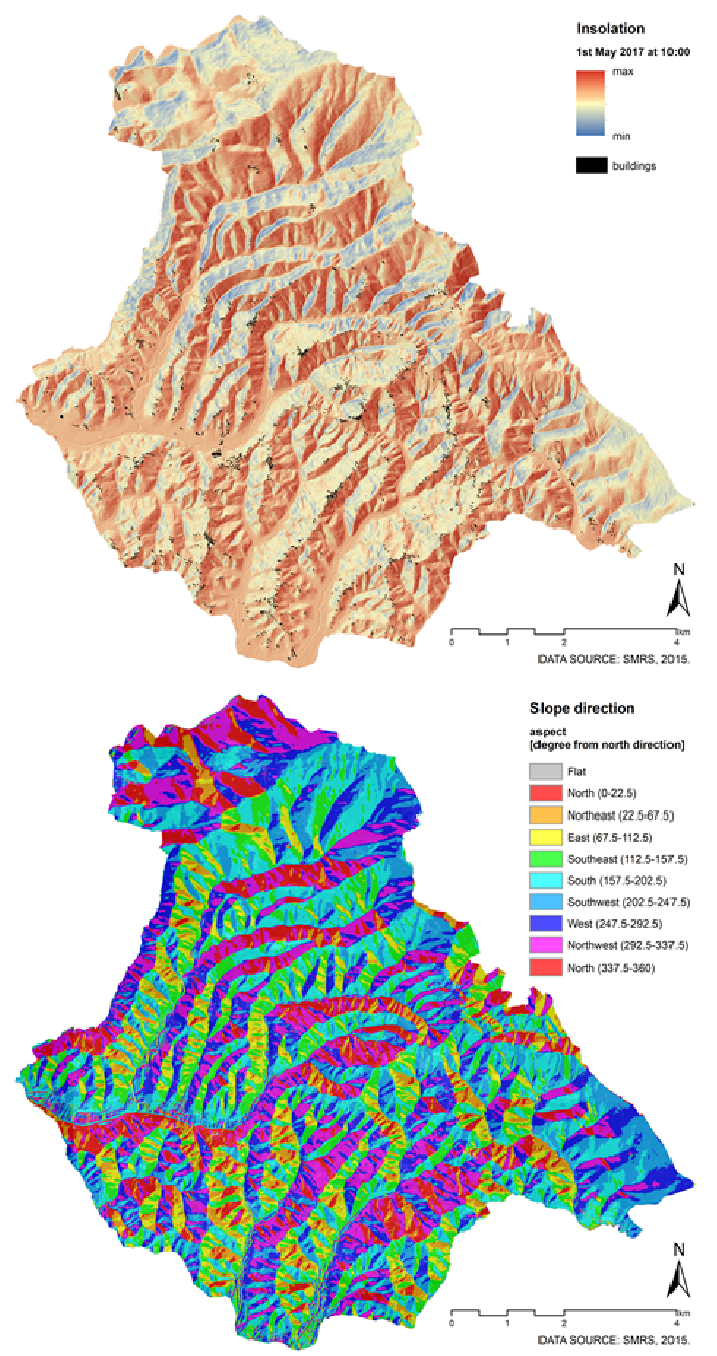

The steepness (slope) of the area varies between 16\% and 30\% (Štabuc et al., 2007) with around 40\% of the area with a slope between 12-20 (Perko et al., 1998). The area is also characterised by typical land structure and terrain diversity, an interconnection between the settlement shape and field allotment. A distinctive feature of hilly and low mountain areas is land allotment into irregular blocks (Kladnik, 1998).

In terms of viticulture, some of the most significant climate factors influencing the growing conditions are the following: high exposure and sun insolation that increases up to $70 \%$ depending on the variation in topographic features, orientation, and elevation (Gajser, 2016), between 1500 and 2500 hours of sunshine annually (Maljevič et al., 2003), see also Fig. 2, and with an average annual precipitation amount of $1,500 \mathrm{~mm}$, receiving most of the precipitation in late spring and in autumn (Jenko et al., 2015). The mean annual temperature is $12.4^{\circ} \mathrm{C}$, the mean monthly temperature is from $3.9^{\circ} \mathrm{C}$ to $21.1^{\circ} \mathrm{C}$ (RibereauGayon et al., 2006). The temperatures exceed $10^{\circ} \mathrm{C}$ more than 210 days a year (Gajser, 2016). Because of terrain diversity and the inflow of warm and humid air masses from the South (fog in the valleys) and exposure to the northeasterly wind Burja, there are several micro climate differences that the local inhabitants take into account both in agriculture and settlement (Jenko et al., 2015).

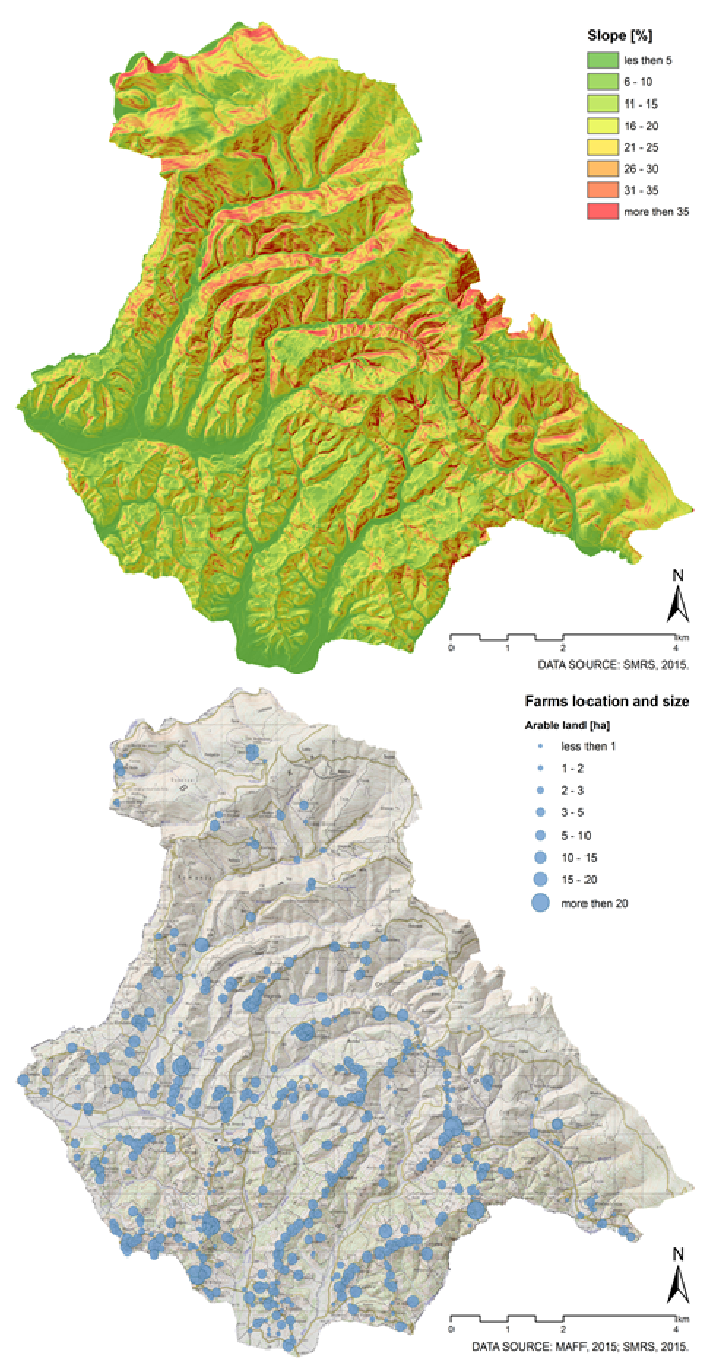

Fig. 2. Some environmental characteristics of the Goriška brda study area 


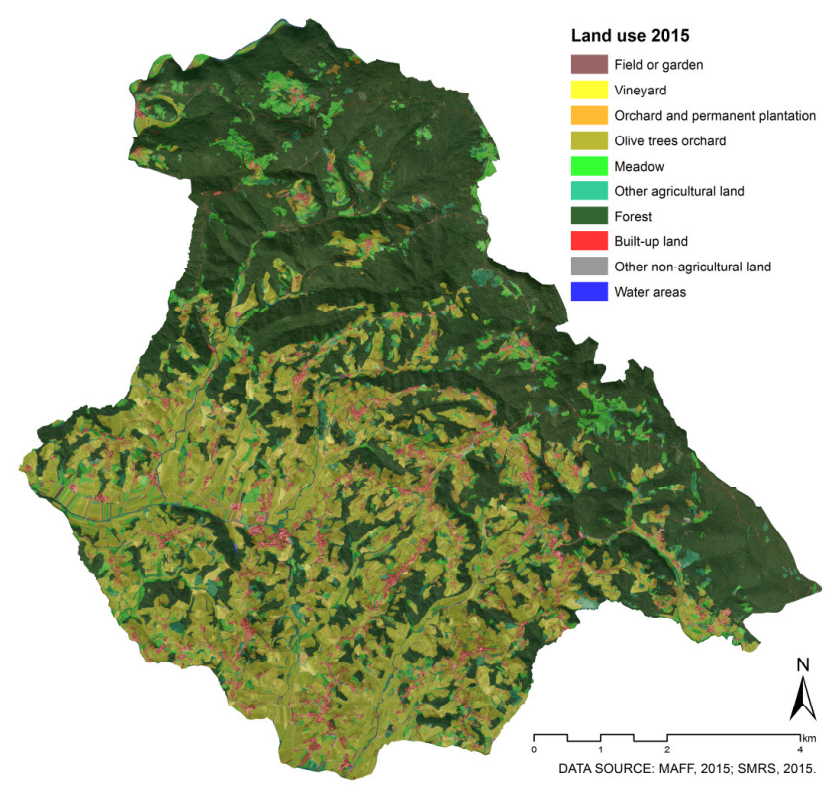

Fig. 3. Land uses in Goriška brda, 2015

Three of the aspects important for the winegrowing in Goriška brda are represented in Fig. 2. The representations on the left reflect the importance of high sun exposure and insolation that depends on orientation, elevation, slope direction, and other topographic features. The high insolation already in the morning, for example, plays an important role in preventing frost damage in early spring. Another key factor is the steepness (slope) of the area shown on the right, which importantly influenced the cultivation pattern (terraces), landscape structure, and the settlement structure in terms of farm locations and distribution.

Ever since Goriška brda has been first settled, its land has been continuously used for winegrowing on cultivated terraces (Fikfak et al., 2015). Goriška brda remained in the colonate system until the end of the Second World War. The features of the colonate imprinted on the social, agricultural, and also cultural life in the area - in terms of land cultivation, land distribution, and real estate structure, found also in modern-day cooperatives (Balkovec, 1996; Podveršič, 1999).

The ecosystem in Goriška brda is threatened primarily because of human actions and reckless human interference in nature: due to the growing exploitation of space intended for agriculture the stability of the system is changing, which is highly sensitive as it is due to its geomorphological structure. The fine structure of agricultural land use (related to operation of individual farms) is not only a consequence of the current administrative and governance practice and plot divisions (inheritance, agrarian reform), but rather it corresponds to the diversity of the terrain and crop rotations (Fikfak et al., 2015). Among the main problems that winemaking and fruit-growing in the region have faced is protecting soil against erosion, prevention of sliding, and too frequent droughts (Zorn and Komac, 2009). The use of cultivated terraces made agriculture possible and prevented the erosion of high-quality fertile soil (Kladnik et al., 2017; Šmid Hribar et al., 2017), although sometimes, as several authors have pointed out, this is not the best solution (Durán Zuazo et al., 2011).

\section{Analyses of land use, land use change in Goriska brda}

The analyses of land use take place in a predominantly rural area occupied mainly by vineyards in the south-west and by forest in the northeast (Fig. 3). The study conducted integrates geospatial technologies and different spatial data (land use, surface data, etc.) with the purpose to understand how people use and develop the land in Goriška brda when trying to turn the natural land resources into a beneficial output.

The possible transitions between the land use categories are shown using a matrix of all changes. With land use types that include several categories, the individual segments of the most likely changes are combined into land use flows land use sequences. The flows combine the activities in space and represent combined steps of changing between the transient conditions of the individual use (Fig. 4).

In the research conducted the elements of landscape morphology and land use development of vineyard areas are articulated with an emphasis on the changing landscapes and sustainable agricultural development. Combined research methodologies used implement different data in land use and land change analyses:

- Historical land cadastral maps were acquired from the Register of Cultural Heritage, Ministry of Culture (RCH, 2017) and from the Surveying and Mapping Authority of the Republic of Slovenia (SMRS, 2015). Mapping and analyses of landscape history (origin, developing phases, and key alterations).

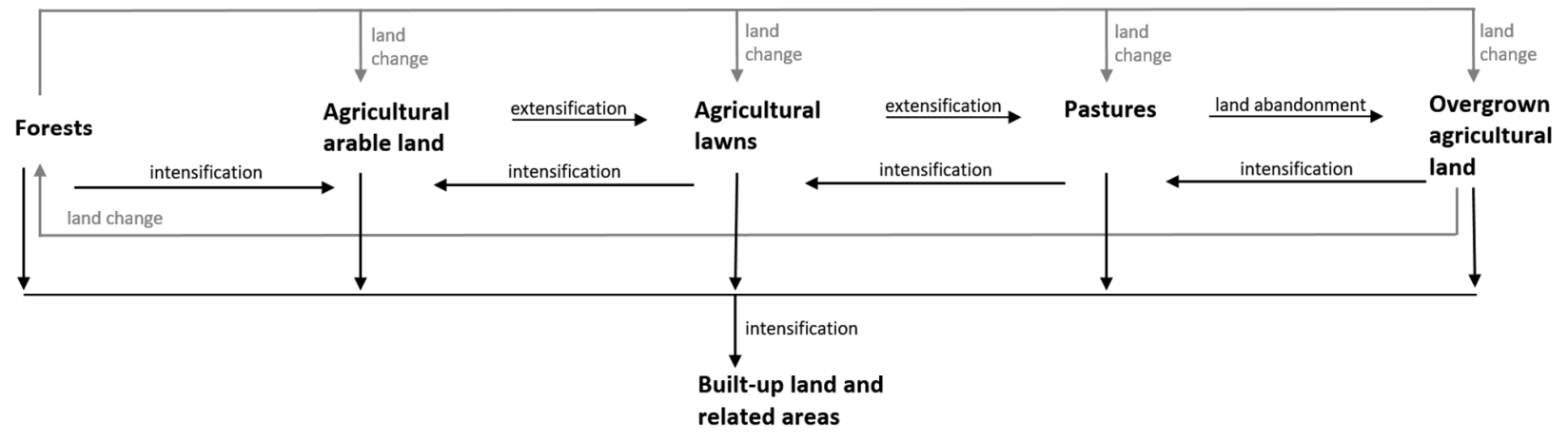

Fig. 4. Transition and transitional processes between actual (main) land use categories 
- Fieldwork and photographs: landscape site visits and street views dated from 2002-2017, systematically undertaken mainly in spring (AprilMay) and autumn (October-November), when the changes in vineyards are most likely to occur.

- Landscape morphology data (settlement pattern, farm location and size) acquired from the Surveying and Mapping Authority (SMRS, 2015) and the Ministry of Agriculture of the Republic of Slovenia (MAFF, 2015). Analyses of morphology using GIS mapping using the ESRI ArcGIS software (ArcMap version 10.3.1).

- Geomorphological data (topography, reliefs, terrain type, and climate conditions) (Fig. 2). All the analyses conducted are based on the created digital elevation model (DEM) for Goriška brda. The analysis of insolation was done for the reference day and time, $1^{\text {st }}$ of May 2017 at 10:00. The hour of the observation was chosen due to the fact that insolation in the morning has an important role in preventing frost damage in early spring. A solar insolation map was produced according to the position of the sun (elevation, azimuth) at the selected date and time. An analysis of terrain orientation that indicates the slope direction was undertaken. The values of each cell in the result raster indicate the compass direction that the surface faces at that location. This enables the identification of south-oriented slopes that are more appropriate for vineyards. Slope analysis gives the information about the rate of change of elevation. The data used were acquired from the Surveying and Mapping Authority of the Republic of Slovenia (SMRS, 2015).

- Land use data from different time periods. The analysis is based on overlaying vector land use data acquired from the agricultural ministry of Slovenia (MAFF, 2015). Land use records of agricultural and forest land use are considered as the only systematic data collection about the actual land use in Slovenia (Miličić and Udovč, 2012). Firs set of land use data was available in 2002. After that the dataset was updated in 2005, 2009, 2012, and 2015. Hence, the land use analyses were conducted for five periods: 2002-2005, 2005-2009, 20092012, 2012-2015, and 2002-2015, which provided an overview of the land use change in Goriška brda. These data were used in the land change cross-tabulation matrix which enabled the identification of the strongest landscape transitions. Due to the influence of the methodology for land use data acquisition in every time point, the results should comprise the information on the characteristics of the data used and their impact on the results (Lisec et al., 2013). The limitations are mostly related to the delineation of built-up areas. The detail of the acquisition sometimes also affects other categories, which results in a few minor changes that do not greatly affect the results of this study.

The primary use of the land use records used for the analyses for the agricultural sector is reflected in the land use classes and land use types of the data (Lisec et al., 2013). To analyse vineyards and land use change in the study area we defined ten new land use classes, which reflected the categories important for the analyses. This was done by reclassifying the land use classes from the original nomenclature (Table 1).

The analyses were conducted in the ESRI ArcGIS environment (ArcMap 10.3.1). Overlaying, intersecting and dissolving of vector data layers from discussed time periods provided information about the location of different type of changes of vineyards that occur in the case study area. The analysis of land use changes was based on the use of the cross-tabulation matrix and the Intensity Analyses methodology presented in Pontius et al. (2004). With the use of the cross-tabulation matrix, we could gain as much insight as possible concerning the potential processes that determine a pattern of land change. According to Aldwaik and Pontius (2012), the cross-tabulation matrix is a fundamental starting point in the analyses of land change. It allows the analyses of different type of changes, from total change of land categories, net change, swap, to gross gains and gross loss of each land use category. At the same time the methodology accounts for land persistence, preservation of particular land use categories, which is usually neglected in land change analyses, even though it is equally important for the understanding of land development. In most cases the persistence of a certain land use category is much larger than its change.

Table 1. Reclassification of the land use data nomenclature used by MAFF (2015)

\begin{tabular}{|c|c|c|c|}
\hline \multicolumn{2}{|c|}{ New land use classification } & \multicolumn{2}{|r|}{ Land use classification } \\
\hline ID & Name & ID & Name \\
\hline \multirow{4}{*}{11} & \multirow{4}{*}{ Field or garden } & 1100 & Field or garden \\
\hline & & 1130 & Temporary meadow \\
\hline & & 1180 & Field with permanent plants \\
\hline & & 1190 & Greenhouse \\
\hline \multirow{2}{*}{121} & \multirow{2}{*}{ Vineyard } & 1211 & Vineyard \\
\hline & & 1212 & Vine field for grape nurseries \\
\hline \multirow{3}{*}{122} & Orchard and other & 1221 & Intensive orchard \\
\hline & permanent & 1222 & Extensive orchard \\
\hline & plantations & 1240 & Other permanent plantations \\
\hline \multirow[t]{2}{*}{123} & \multirow[t]{2}{*}{ Olive trees orchard } & 1230 & Olive trees orchard \\
\hline & & 1300 & Permanent meadow \\
\hline \multirow{4}{*}{13} & \multirow{4}{*}{ Meadows } & 1321 & Marshy meadow \\
\hline & & 1330 & Mountain meadow \\
\hline & & 1800 & Grass meadow with forest trees \\
\hline & & 1410 & Overgrown agricultural land \\
\hline \multirow{3}{*}{14} & \multirow{3}{*}{$\begin{array}{l}\text { Other agricultural } \\
\text { land }\end{array}$} & 1420 & Plantation of forest trees \\
\hline & & 1500 & Trees and bushes \\
\hline & & 1600 & Uncultivated agricultural land \\
\hline 20 & Forest & 2000 & Forest \\
\hline \multirow[t]{2}{*}{30} & \multirow[t]{2}{*}{ Built-up land } & 3000 & Built-up land and related areas \\
\hline & & 4100 & Marshland \\
\hline \multirow{4}{*}{50} & \multirow{4}{*}{$\begin{array}{l}\text { Other non- } \\
\text { agricultural land }\end{array}$} & 4210 & Reeds \\
\hline & & 4220 & Other wetland \\
\hline & & 5000 & $\begin{array}{l}\text { Dry land with specific vegetation } \\
\text { cover }\end{array}$ \\
\hline & & 6000 & $\begin{array}{c}\text { Barren land with negligible or no } \\
\text { vegetation }\end{array}$ \\
\hline 70 & Water areas & 7000 & Water areas \\
\hline
\end{tabular}


Table 2. Cross-tabulation matrix for land use comparison between different points in time (Pontius et al., 2004)

\begin{tabular}{|c|c|c|c|c|c|}
\hline \multirow{2}{*}{ Time 1} & \multicolumn{3}{|c|}{ Time 2} & \multirow{2}{*}{ Total time 1} & \multirow{2}{*}{ Gross Loss } \\
\hline & Category 1 & Category 2 & Category 3 & & \\
\hline Category 1 & $P_{11}$ & $\mathrm{P}_{12}$ & $\mathrm{P}_{13}$ & $\mathrm{P}_{\mathrm{l}_{+}}$ & $\mathrm{P}_{1++}-\mathrm{P}_{11}$ \\
\hline Category 2 & $\mathrm{P}_{21}$ & $\mathrm{P}_{22}$ & $\mathrm{P}_{23}$ & $\mathrm{P}_{2+}$ & $P_{2+}-P_{22}$ \\
\hline Category 3 & $\mathrm{P}_{31}$ & $\mathrm{P}_{32}$ & $\mathrm{P}_{33}$ & $\mathrm{P}_{3+}$ & $\mathrm{P}_{3+}-\mathrm{P}_{33}$ \\
\hline Total time 2 & $\mathrm{P}_{+1}$ & $\mathrm{P}_{+2}$ & $\mathrm{P}_{+3}$ & 1 & \\
\hline Gross Gain & $\mathrm{P}_{+1}-\mathrm{P}_{11}$ & $\mathrm{P}_{+2}-\mathrm{P}_{22}$ & $\mathrm{P}_{+2}-\mathrm{P}_{33}$ & & \\
\hline
\end{tabular}

A case of a transition matrix of land use change is given in Table 2. The rows display the categories in time ' 1 ', the columns the categories in observed time ' 2 '. ' $\mathrm{P}_{\mathrm{ij}}$ ' denotes the change in land use occurred from category ' $i$ ' to category ' $j$ '. The entries on the diagonal indicate persistence of each category. Entries off the diagonal indicate the conversion elasticity of individual land use categories. Two more columns are added to the matrix, showing the total proportion of each category in time 1 and the gross loss of each category between time 1 and time 2 . The additional rows show the totals of land use categories in time 2 and gross gains of every category.

The data from the cross-tabulation matrix for each time interval serve to calculate the net change of categories (difference between totals in time 1 and time 2), the swap occurred in each category (category change in location with no change in proportion of land use category) and the total change that includes both gains and losses of each category. Only the combination of different types of change can explain the whole picture and enables to identify the most important transitions among the categories. For the analyses of land use change often only the net changes are observed. The lack of knowledge and the limitations delivered from the data allow only for the comparison of the quantity of each land use category between the analysed years. The shortcoming of the land change analyses based only on net change is that it might greatly underestimate the total change on the landscape, since the net change fails to capture the swapping component of change. A lack of net change does not necessarily indicate a lack of change (Pontius et al., 2013).

Additional examination of the off-diagonal entries in the cross-tabulation matrix enables to identify the most important transitions and to distinguish between a clearly systematic landscape transition and a seemingly random landscape transition. To identify systematic transitions within the transition matrix, one must interpret the land use changes relative to the sizes of the categories. The examination was carried out as suggested in Pontius et al. (2004) both in terms of gains and losses. In both cases one must interpret the change relative to the size of the categories. The analyses of gains assume that the gain of each category and the proportions of the categories are fixed. The total gain is then distributed to other categories accordingly to their relative proportion. Similarly, in the analyses of losses the loss of each category is fixed and then distributed across the other categories according to their relative proportion. In both cases the distribution represents a random process of change, influenced only by the sizes of the categories. The values calculated represent the percent of the landscape that would be expected to change (as gain or loss of the observed category), if the transitions would occur randomly. For the examination two additional values are calculated for each transition: the difference between the observed and expected proportion of change and the relative difference, which is calculated by dividing the calculated difference by the expected value.

\section{Results and Discussion}

According to the land use data in 2002, the prevailing land use class in Goriška brda is forest (49\%), followed by vineyards (26\%), meadows, orchard and other permanent plantations, built-up land, field or garden, other agricultural land, other non-agricultural land, and water bodies. A simple comparison of land uses in the last reference year (2015) showed a similar result and indicated relatively small land use changes. The two highest changes were a $1.9 \%$ increase in orchard and other permanent plantations and a $1.6 \%$ decrease in fields and gardens. The calculation of a cross-tabulation matrix revealed that the changes were much more intense and frequent.

The results from the comparison of land use in 2002 and 2015 with the cross-tabulation matrix were gathered in Table 3. All the results were shown in $\%$ as this enabled a more efficient comparison.

As we can see almost $25 \%$ of land underwent some sort of land use change in the observed period. That does not mean that $25 \%$ of the land in 2015 was categorized with a different land use category than in 2002, it only shows the amount of land that changed. The progressive colours in the table represent the size of a different type of change: red the highest gains; green the highest losses, blue to brown the distribution of net change, and orange the total change. The comparison of net changes and total changes showed that even if the net change of the category of vineyards was only $0.2 \%$, the category changed considerably. The total change of this category was the highest of all, $11.3 \%$. The analyses of gains, losses, and net change of all categories showed the categories that change the most and whether this was by gaining or losing the proportion of the landscape. The categories that lost the highest proportion of landscape were the categories fields and gardens, meadows and forest. On the other hand, the proportion increased most in benefit of the category orchard and other permanent plantations.

Analysing in detail the land change of vineyards areas showed the details of a high percentage of swamp of this category. Table 4 shows the most important gains and losses of the category of vineyards regarding other observed categories in all observed time periods. The results are presented in \%.

The colours red and green show the highest gains and losses of vineyards land category in each period observed. For both gains and losses, we notice that both changes of vineyards occurred mainly with two categories (orchard and other 
Table 3. Comparison of the land use categories between 2002 and 2015

\begin{tabular}{|c|c|c|c|c|c|c|c|c|c|c|}
\hline \multirow{2}{*}{ Changes observed } & \multicolumn{10}{|c|}{ Land use categories } \\
\hline & 11 & 121 & 122 & 123 & 13 & 14 & 20 & 30 & 50 & 70 \\
\hline Land use in 2002 & 2.0 & 26.4 & 5.3 & 0.0 & 9.5 & 3.5 & 48.8 & 4.3 & 0.0 & 0.1 \\
\hline Gain & 0.2 & 5.6 & 4.7 & 0.6 & 4.7 & 3.6 & 3.8 & 1.2 & 0.0 & 0.1 \\
\hline Loss & 1.9 & 5.8 & 2.8 & 0.0 & 5.8 & 2.8 & 4.5 & 1.0 & 0.0 & 0.0 \\
\hline Swamp & 0.5 & 11.2 & 5.6 & 0.0 & 9.4 & 5.6 & 7.6 & 2.0 & 0.0 & 0.1 \\
\hline Persistence & 0.1 & 20.6 & 2.5 & 0.0 & 3.7 & 0.7 & 44.3 & 3.4 & 0.0 & 0.1 \\
\hline Land use in 2015 & 0.4 & 26.2 & 7.2 & 0.6 & 8.3 & 4.3 & 48.1 & 4.6 & 0.0 & 0.2 \\
\hline Net Change & -1.6 & -0.2 & 1.9 & 0.6 & -1.1 & 0.8 & -0.7 & 0.3 & 0.0 & 0.1 \\
\hline \multirow[t]{6}{*}{ Total Change } & 2.1 & 11.3 & 7.5 & 0.6 & 10.5 & 6.4 & 8.3 & 2.2 & 0.0 & 0.1 \\
\hline & & \multicolumn{5}{|c|}{ LEGEND } & & & & \\
\hline & & \multicolumn{2}{|c|}{ Min } & Max & \multicolumn{2}{|c|}{ Gain } & & & & \\
\hline & & \multicolumn{2}{|c|}{ Min } & $\operatorname{Max}$ & \multicolumn{2}{|c|}{ Loss } & & & & \\
\hline & & \multicolumn{2}{|c|}{ Min } & $\operatorname{Max}$ & \multicolumn{2}{|c|}{ Net Change } & & & & \\
\hline & & \multicolumn{2}{|c|}{ Min } & $\operatorname{Max}$ & \multicolumn{2}{|c|}{ Total Change } & & & & \\
\hline
\end{tabular}

Table 4. Gains and losses of the vineyards category

\begin{tabular}{|c|c|c|c|c|c|c|c|c|c|c|c|}
\hline \multirow{2}{*}{\multicolumn{2}{|c|}{ Observed time periods }} & \multicolumn{10}{|c|}{ Observed land use categories } \\
\hline & & 11 & 122 & 123 & 13 & 14 & 20 & 30 & 50 & 70 & Total \\
\hline \multirow{2}{*}{$2002-2005$} & Gain & 0.42 & 0.57 & 0.00 & 0.62 & 0.14 & 0.42 & 0.09 & 0.00 & 0.00 & 2.26 \\
\hline & Loss & 0.15 & 0.71 & 0.01 & 0.33 & 0.07 & 0.13 & 0.15 & 0.00 & 0.00 & 1.55 \\
\hline \multirow{2}{*}{$2005-2009$} & Gain & 0.36 & 1.45 & 0.02 & 0.84 & 0.19 & 0.86 & 0.08 & 0.00 & 0.00 & 3.79 \\
\hline & Loss & 0.05 & 0.77 & 0.12 & 0.74 & 0.45 & 0.33 & 0.21 & 0.00 & 0.00 & 2.68 \\
\hline \multirow{2}{*}{ 2009-2012 } & Gain & 0.02 & 0.20 & 0.01 & 0.28 & 0.26 & 0.24 & 0.10 & 0.00 & 0.00 & 1.11 \\
\hline & Loss & 0.02 & 0.57 & 0.04 & 0.58 & 0.58 & 0.14 & 0.17 & 0.00 & 0.00 & 2.10 \\
\hline \multirow{2}{*}{$2012-2015$} & Gain & 0.02 & 0.17 & 0.00 & 0.20 & 0.36 & 0.33 & 0.04 & 0.00 & 0.00 & 1.12 \\
\hline & Loss & 0.08 & 0.62 & 0.10 & 1.04 & 0.24 & 0.02 & 0.06 & 0.00 & 0.00 & 2.15 \\
\hline \multirow{2}{*}{$2002-2015$} & Gain & 0.72 & 1.43 & 0.00 & 1.38 & 0.40 & 1.49 & 0.15 & 0.00 & 0.00 & 5.58 \\
\hline & Loss & 0.12 & 1.89 & 0.28 & 2.06 & 0.72 & 0.30 & 0.40 & 0.00 & 0.01 & 5.77 \\
\hline & & \multicolumn{5}{|c|}{ Legend } & & & & & \\
\hline & & Min & & Max & \multicolumn{2}{|c|}{ Gain } & & & & & \\
\hline & & Min & & Max & \multicolumn{2}{|c|}{ Loss } & & & & & \\
\hline
\end{tabular}

permanent plantations and meadows). At the same time vineyards constantly gained in regard to forest. In the first two time periods observed the gain of vineyards that replaced the categories field or garden was notable. The most changes occurred between agricultural land categories that have a high conversion elasticity. Land use transition sequences were quite frequent and they mainly happened between the categories of vineyards, orchard and other permanent plantations, meadows and forest.

Then we separately analysed only the land category of vineyards. Table 5 shows the proportion of the landscape occupied by vineyards in each year, the persistence of the category in each time period, and the percentage of all five types of change.

The analyses of gains and the analyses of losses (Fig. 5) showed that the category of vineyards changed the most between 2005 and 2009. After 2009 the quantity of changes decreased, but did not stop. During the whole time span the persistence of the category of vineyards was quite high, i.e. around $20 \%$. This shows that the landscape does not change substantially. In this way, the important visual characteristics of the winegrowing district are preserved, and thus also the image of the typical Brda cultural landscape.

The analyses of change location gave additional informa- tion about the undergoing process of change in space. The visually analyses helped to link patterns to processes. Fig. 6 presents the locations of gains and losses between every period observed. Due to a high number of minor changes only the areas of gains and losses larger than 0.5 ha are shown. The changes exceeding 0.5 ha represent a loss in more than $70 \%$ of vineyard areas between 2002 and 2005 and as much as $85 \%$ of all acquired, new areas.

The comparison of the locations of vineyard changes, in Fig. 6, revealed the different intensity of changes in time. In every time period the location of changes varied throughout the territory observed. The spatial dynamics of the changes was great, particularly if looking at the fragmentation of changes. The changes were small and numerous, which is a consequence of surface features, dispersion of farmsteads, and their land ownership structure.

Some spatial characteristics of the land use changes in Goriška brda were revealed only when analysing the changes over a longer time interval (Fig. 7).

Additionally, Hot Spots analysis in $\operatorname{Arc} G I S$ environment was used to show the hot spots of changes, both in terms of gains and losses in the vineyards category. The result is shown on Fig. 8. 
618

Table 5. Overall changes of the vineyard category for the observed time periods in \%

\begin{tabular}{cccccccccc}
\hline Time interval & $\begin{array}{c}\text { Status } \\
\mathrm{t}\end{array}$ & $\begin{array}{c}\text { Status } \\
\mathrm{t}+1\end{array}$ & Gain & Loss & Persistence & Total change & Swamp & Net change \\
\hline $2002-2005$ & 26.41 & 27.12 & 2.26 & 1.55 & 24.86 & 3.81 & 3.09 & 0.72 \\
$2005-2009$ & 27.12 & 28.24 & 3.79 & 2.68 & 24.44 & 6.47 & 5.36 & 1.12 \\
$2009-2012$ & 28.24 & 27.25 & 1.11 & 2.10 & 26.14 & 3.21 & 2.22 & -0.99 \\
$2012-2015$ & 27.25 & 26.21 & 1.12 & 2.15 & 25,09 & 3.27 & 2.24 & -1.03 \\
$2002-2015$ & 26.41 & 26.21 & 5.58 & 5.77 & 20.64 & 11.35 & 11.15 & -0.19 \\
\hline
\end{tabular}

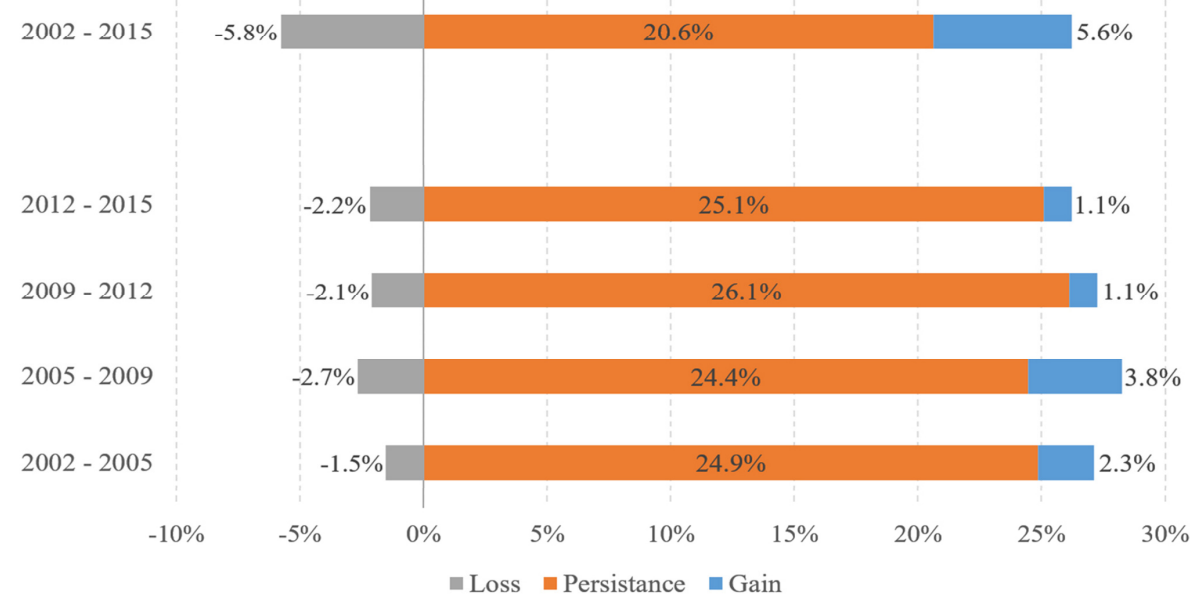

Fig. 5. Gain, persistence and loss of vineyard category
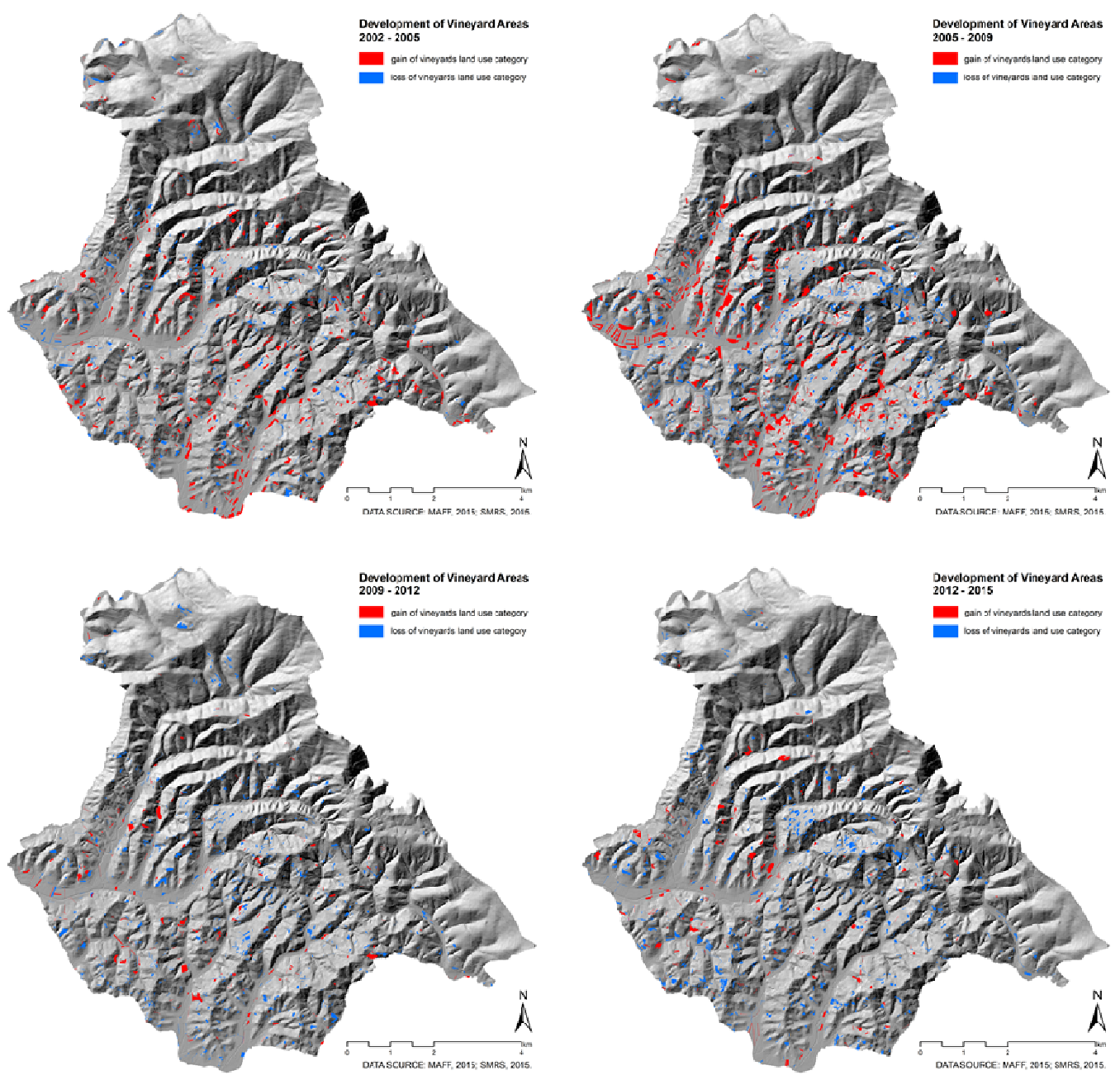

Fig. 6. Losses and gains of surfaces by the vineyard land use category 


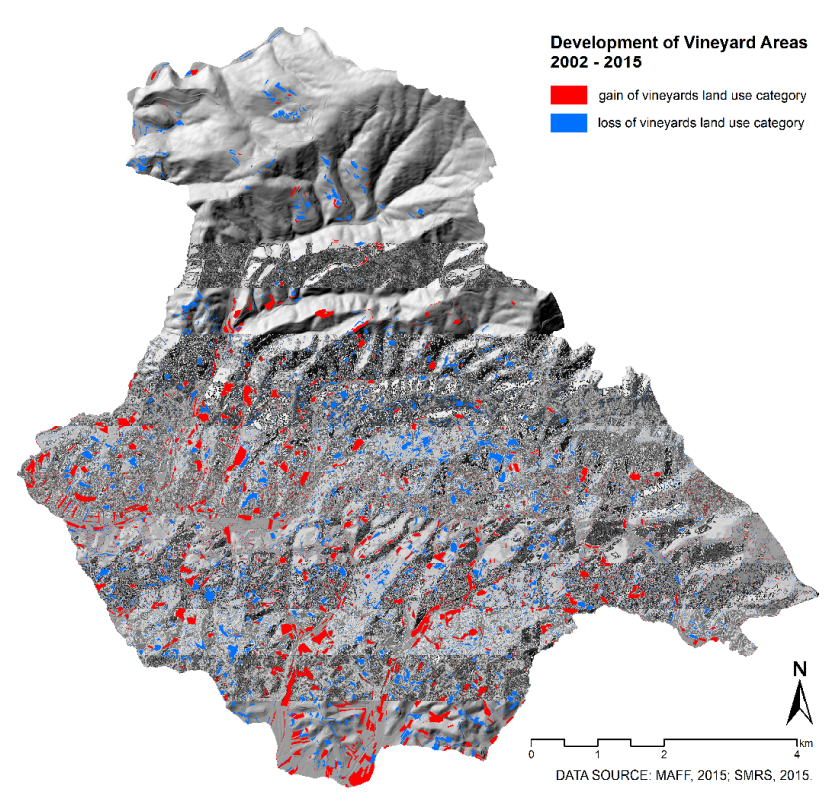

Fig. 7. Losses and gains of surfaces in the vineyards land use category from 2002 to 2015

The last part of this study was the examination of the off-diagonal entries of the cross-tabulation matrix that represent the cross-category changes, gains and losses between categories. This was done for the 2002-2015 crosstabulation matrix to identify the seemingly random and systematic landscape transition. We analysed the changes in terms of gains and separately in terms of losses. For each analysis we calculated the percentage of the landscape that would be expected to change in a random process of gain or loss. For the identification of systematic changes two additional values were calculated: the difference between the observed and expected transition that gives the information about the deviation from a random process of change, where changes are distributed according to the sizes of the categories, and the relative difference of every change that indicates the difference between the observed value and the expected value, relative to the magnitude of the expected value. The selected results important for vineyard areas are presented in Table 6.

If the difference in the analyses of gains is positive, then the category in the row lost more to the category in the column than would be expected by any random process of gain in that category of the column. On the other hand, if the difference is negative, then the category in the row lost less to the category in the column than would be expected. This happened in the case of Forest. The change from Vineyard to Forest (approx. 107 ha or almost 1.5\% of the whole area) was one of the largest changes between categories observed. But it was due to the size of the category Forest (in 2002 almost 49\%), so a bigger change would be expected. That is the reason behind the conclusion that when Vineyard gains, it does not replace Forest. From the recognized systematic transitions, there are two more that shape the landscape in Goriška brda. The first is the transition of Fields and Garden to Vineyard. When Vineyard gains, it systematically replaces Field and Garden at a rate over 3 times the rate that would be expected from a random process of gain. The second refers to when the category Olive Trees Orchard gains - it is inclined to gain from Vineyards systematically.

The interpretation was different in the analysis of losses. The logic was the same, but the role of the rows and columns in the cross-tabulation matrix was switched. Therefore, if the calculated difference between actual and expected percent of change was positive, then the category in the column gained more from the category in the row than would be expected. If the difference was negative, this meant that the category in the column gained less from the category in the row than expected. The results of the analyses showed that when the category Field or Garden loses, Vineyard tends to replace it. A distinct change was also the loss of Vineyards - when the category loses, it tends to be systematically replaced by Meadows and Orchard and Other Permanent Plantation but not by Forest.

Table 6. The most systematic transitions of vineyards category

\begin{tabular}{|c|c|c|c|c|c|}
\hline Transition & $\begin{array}{l}\text { Observed } \\
\text { transition }\end{array}$ & $\begin{array}{l}\text { Expected } \\
\text { transition }\end{array}$ & $\begin{array}{c}\text { Observed } \\
\text { minus expected }\end{array}$ & $\begin{array}{l}\text { Difference divided } \\
\text { expected }\end{array}$ & Interpretation of systematic transition \\
\hline \multicolumn{6}{|c|}{ In terms of gains } \\
\hline 122 to 121 & 1.43 & 0.40 & 1.03 & 2.57 & $\begin{array}{l}\text { When vineyard gains, it replaces orchard and other permanent } \\
\text { plantation. }\end{array}$ \\
\hline 11 to 121 & 0.72 & 0.15 & 0.57 & 3.76 & When vineyard gains, it replaces field or garden. \\
\hline 20 to 121 & 1.49 & 3.70 & -2.21 & -0.60 & When vineyard gains, it does not replace forest \\
\hline 121 to 13 & 2.06 & 1.37 & 0.69 & 0.50 & When meadow gains, it replaces vineyard. \\
\hline 121 to 122 & 1.89 & 1.32 & 0.56 & 0.43 & $\begin{array}{c}\text { When orchard and other permanent plantation gains, it replaces } \\
\text { vineyard. }\end{array}$ \\
\hline 121 to 123 & 0.28 & 0.17 & 0.12 & 0.69 & When olive trees orchard gains, it replaces vineyard. \\
\hline 121 to 20 & 0.30 & 1.95 & -1.65 & -0.85 & When forest gains, it does not replace vineyard. \\
\hline \multicolumn{6}{|c|}{ In terms of losses } \\
\hline 122 to 121 & 1.43 & 0.79 & 0.64 & 0.80 & When field or garden loses, vineyard replaces it. \\
\hline 20 to 121 & 1.49 & 2.27 & -0.78 & -0.34 & When forest loses, vineyard does not replace it. \\
\hline 121 to 13 & 2.06 & 0.65 & 1.40 & 2.15 & When vineyard loses, meadow replaces it. \\
\hline 121 to 122 & 2.06 & 0.65 & 1.40 & 2.15 & $\begin{array}{l}\text { When vineyard loses, orchard and other permanent plantation } \\
\text { replace it. }\end{array}$ \\
\hline 121 to 20 & 0.30 & 3.76 & -3.46 & -0.92 & When vineyard loses, forest does not replace it. \\
\hline
\end{tabular}




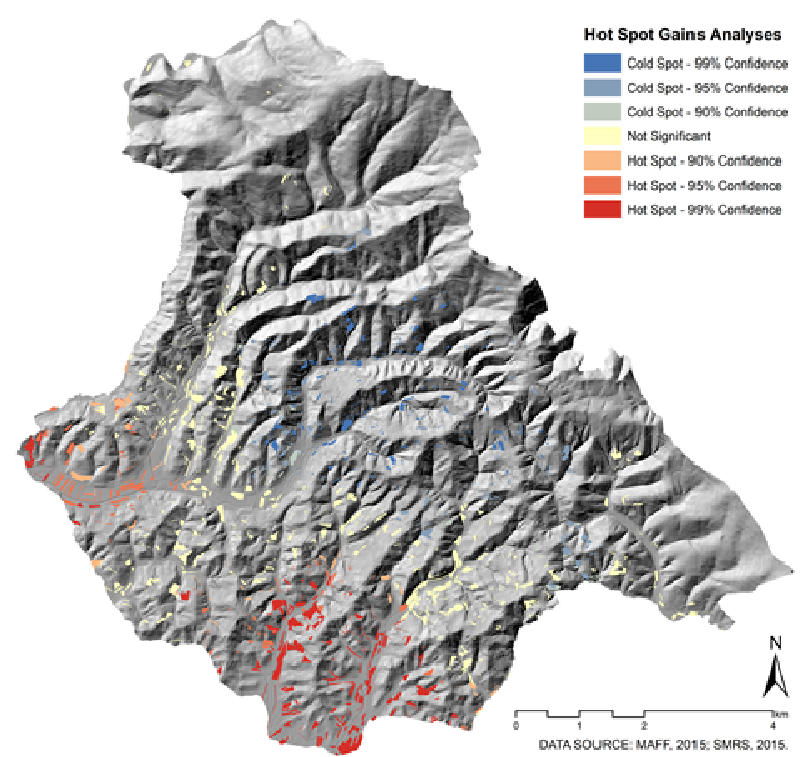

Fig. 8. Areas of intensive change (gains and losses) of vineyards

\section{Conclusions}

The paper presents detailed analyses of land use change, based on the existing cross-tabulation matrix methodology, between land use categories in several time intervals for a vineyard area of Goriška brda, Slovenia. The analyses were conducted for a wide span of land use data available (from 2002 to 2015) for Slovenia. The changes in land categories, particularly vineyards, were analysed according to the net change and swap of the categories and the gross gains and gross losses of the categories in comparison with other land use categories. Additionally, it was found that the existing method fails to analyse the location of change and the spatial distribution of changes. For this reason, visual and hot spot analyses of the locations where changes occur were suggested. The hot spot analyses gave additional information about the undergoing process of change in space. By comparing land use categories over several time periods, the study determined that during the whole time span the persistence of the category of vineyards was quite high, i.e. around $20 \%$. This shows that the landscape does not change substantially, but nevertheless, important changes are present. It was found that the size and speed of changes varied across different time intervals. The spatial dynamic of change is high causing the fragmentation of land use. The changes are small and numerous, which is a consequence of surface features, dispersion of farmsteads, and their land ownership structure. It was demonstrated that the land use category of vineyards changes most of the time seemingly randomly, except in some cases when land changes occur systematically, like in the case when vineyards were systematically changed by meadows between 2012 and 2015. Because of the height value of swamp and height persistence of the vineyard category, the ongoing changes still do not affect the landscape. The important visual characteristics of the winegrowing district are preserved, and thus also the image of the typical Brda cultural landscape. By recognizing systematic land use changes, the study identified the most important trends that might shape the transformative agrarian landscape in the future. Researching

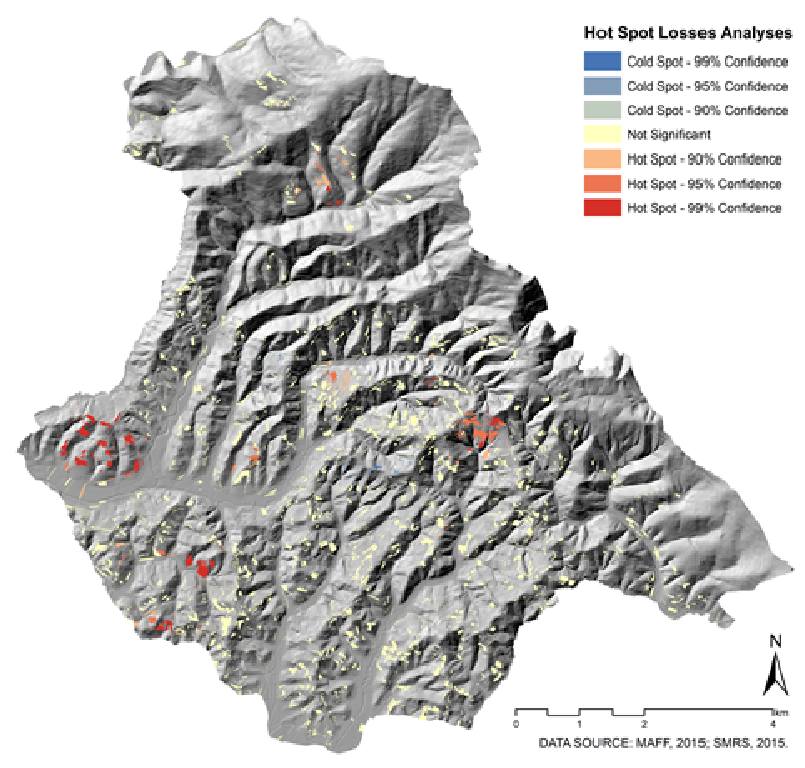

the drivers and reasons behind these systematic changes could be one of the next steps in studying land use development in Goriška brda. The research of land use development carried out on the case study of "Goriška Brda" is relevant both for the assessment of the present state and from the point of future changes but also from the aspect of the settlement structure as winegrowing carries on the tradition of living culture, survival and natural balance.

\section{Acknowledgements}

This paper is published in the framework of the project: KLABS - Creating the Network of Knowledge Labs for Sustainable and Resilient Environments, 561675-EPP-12015-1-XK-EPPKA2-CBHE-JP.

\section{References}

Aldwaik SZ, Pontius RG (2012). Intensity analysis to unify measurements of size and stationarity of land changes by interval, category, and transition. Landscape and Urban Planning 106:103-114

Amato F, Martellozzo F, Nolè G, Murgante B (2017). Preserving cultural heritage by supporting landscape planning with quantitative predictions of soil consumption. Journal of Cultural Heritage 23:4454.

Antrop M (1993). The transformation of the Mediterranean landscapes: an experience of 25 years of observations. Landscape and Urban Planning 24(1-4):3-13.

Balkovec B, Bajt D, Cvirn J, Drnovšek M, Godeša B, Goropevšek B, ... Svoljšak P (2005). Slovenska kronika XX. Stoletja, [Slovenian Chronicles of theXXth Century].Ljubljana, Nova Revija

Bieling C, Plieninger T, Schaich H (2013). Patterns and causes of land change: Empirical results and conceptual considerations derived from a case study in the Swabian Alb, Germany. Land Use Policy 35:192-203.

Borisov B (2015). General development master plans as tool for solving practical problems in agriculture. Bulgarian Journal of Agricultural Science 21(6):1140-1147. 
Briassoulis H (2000). Analysis of land use change: theoretical and modelling approaches. Regional Research Institute, West Virginia. Web Book. Retrieved 2017 Apr 11 from http://www.rri.wvu.edu/we bbook/briassoulis/contents.htm.

Castañeda LE, Barbosa O (2016). Metagenomic analysis exploring taxonomic and functional diversity of soil microbial communities in Chilean vineyards and surrounding native forests. PeerJ 5:e3098.

Durán Zuazo VH, Rodríguez Pleguezuelo CR, Martin Peinado FJ, De Graaff J, Francia Martínez JR, Flanagan DC (2011). Environmental impact of introducing plant covers in the taluses of terraces: Implications for mitigating agricultural soil erosion and runoff. Catena 84:79-88.

EEA (2004). High nature value farmland. Characteristics, trends and policy challenges. EEA Report No. 1/2004. European Environment Agency. $\begin{array}{lllll}\text { Retrieved } & 2014 & \text { Mar } & 12 & \text { from }\end{array}$ https://www.eea.europa.eu/publications/report_2004_1.

EU-LUPA (2012). European land use patterns. ESPON Applied Research Project 2013/1/8. Vol I - Land Use Characterization in Europe: Analysing land use patterns using typologies. Part C Scientific report. Version 20/November/2012, Espon \& Tecnalia Research \& Innovation. Retrieved 2013 Feb 4 from https://www.espon.eu/programme/projects/espon-2013/appliedresearch/eu-lupa-european-land-use-patterns.

Fikfak A (2008). Naselbinska kultura slovenskega podeželja - Goriška brda, [Rural settlement Culture of Slovenian Countryside - Goriška Brda]. Ljubljana, Faculty of architecture.

Fikfak A, Popović SG, Kosanović S (2015). Settlements patterns in an agrarian landscape - principles of classification in Goriška brda, Slovenia. Agriculture \& Forestry 61(4):319-335.

Gajser A (2016). Uporaba GIS-a za analizo ustreznosti lokacij vinogradov v Goriških brdih, [GIS Analyses of Vineyard Locations Suitability in Goriska Brda].MSc Dissertation, University of Ljubljana.

García-Díaz A, Bienes R, Sastre B, Novara A, Gristina L, Cerdà A (2017). Nitrogen losses in vineyards under different types of soil groundcover. A field runoff simulator approach in central Spain. Agriculture, Ecosystems and Environment 236:256-267.

Gude PH, Hansen AJ, Rasker R, Maxwell B (2006). Rates and drivers of rural residential development in the Greater Yellowstone. Landscape and Urban Planning 77:131-151.

IAMO (2006). Agriculture in the Face of Changing Markets, Institutions and Policies: Challenges and Strategies. In: Curtiss J, Balmann A, Dautzenberg K, Happe K (Eds). Studies on the Agricultural and Food Sector in Central and Eastern Europe. Volume 33. Leibniz, Institut fur Agrarentwicklung in Mittel und Osteuropa. Retrieved 2016 Mar 23 from:https://www.iamo.de/fileadmin/documents/sr_vol33.pdf.

Jangid K, Williams MA, Franzluebbers AJ, Sanderlin JS, Reeves JH, Jenkins MB, ... Whitman WB (2008). Relative impacts of land-use, management intensity and fertilization upon soil microbial community structure in agricultural systems. Soil Biology \& Biochemistry 40:28432853.

Jenko A, Zupančič N, Sunčič T, Kejžar I (2015). Okoljsko poročilo: Spremembe in dopolnitve Občinskega prostorskega načrta Občine Brda, [Environmental Report: Changes and Amendments of the Municipal Spatial Plan of the Municipality of Brda]. IPSUM, okoljske investicije, d.o.o. Retrieved 2017 Mar 12 from: http://www.obcina-
brdasi/mma/OPN\%20Okoljkso\%20poročilo/2016060810495186/.

Kahan D (2013). Market-Oriented Farming: An Overview. In: Farm Management Extension Guide. Rome, Food and Agriculture Organization of the United Nations (FAO).

Kladnik D (1998). Goriška brda. Slovenija - pokrajina in ljudje [Goriška Brda. Slovenia - Its landscape and people]. Ljubljana: DZS.

Kladnik D, Ciglič R, Geršič M, Komac B, Perko D, Zorn M (2016). Diversity of terraced landscapes in Slovenia. In: Žitko $S$ (Ed). Annals for Istrian and Mediterranean Studies. Series Historia et Sociologia 26(3): $469-486$.

KladnikD, Gabrovec M (1998). Raba tal, [Land Use]. In: Fridl J, Kladnik D, Orožen Adamič M, Perko D (Eds). Geografski atlas Slovenije. Država v prostoru in času, [Geographical atlas of Slovenia. The state in space and time].DZS, Ljubljanapp 180-191.

Kladnik D, Kruse A, Komac B (2017). Terraced landscapes: an increasingly prominent cultural landscape type. Acta Geographica Slovenica 57(2):73-81.

Kleijn D, Kohler F, Baldi A, Batary P, Concepcion ED, Clough Y, ... Verhulst J (2009). On the relationship between farmland biodiversity and land-use intensity in Europe. Proceedings of the Royal Society B. Biological Sciences 276(1658):903-909. Retrieved 2017 May 5 from http://rspb.royalsocietypublishing.org/.

Komac B, Zorn M (2005). Soil erosion on agricultural land in Slovenia Measurements of rill erosion in the Besnica valley. Acta Geographica Slovenica 45(1):53-86

Kosmas C, Danalatos N, Cammeraat LH, Chabart M, Diamantopoulos J, Farand R, ... Vacca A (1997). The effect of land use on runoff and soil erosion rates under Mediterranean conditions. Catena 29:45-59.

Lisec A, Pišek J, Drobne S (2013). Analiza primernosti evidence rabe kmetijskih in gozdnih zemljišč za določanje sprememb rabe zemljišč na primeru Pomurske statistične regije [Suitability analysis of land use records of agricultural and forest land for detecting land use change on the case of the Pomurska Statistical Region]. Acta Geographica Slovenica 53(1):71-90.

MaljevičJ, Colarič LM, Jakše M, PožekN (2003). Naravi in ljudem prijazno vinogradništvo [Nature and people friendly wine growing]. Novo mesto,ZavodKGZS.

MAFF (2015). Ministry of Agriculture, Forestry and Food, Republic of Slovenia. Land use data. Retrieved 2015 Apr 12 from http://rkggov.si/GERK/.

Marques MJ, Bienes R, Cuadrado J, Ruiz-Colmenero M, Barbero-Sierra C, Velasco A (2015). Analysing perceptions attitudes and responses of winegrowers about sustainable land management in Central Spain. Land Degradation and Development. Special Issue: Soil Science for Land Management 26(5):458-467.

Matson PA, Parton WJ, Power AG, Swift MJ (1997). Agricultural intensification and ecosystem properties. Science 277(5325):504509.

Mazzocchi C, Sali G, Corsi S (2013). Land use conversion in metropolitan areas and the permanence of agriculture: Sensitivity Index of Agricultural Land(SIAL), a tool for territorial analysis. Land Use Policy 35:155-162.

Miličić V, Udovč A (2012). Uporabnost prostorskih podatkov kmetijskega sektorja za analize sprememb rabe kmetijskih zemljišč na primeru izbranega območja varovanja narave v Sloveniji, [Spatial data utilization of the agricultural sector for the purposes of agricultural land use change 
622 in the case of a selected nature protection area in Slovenia]. Geodetski vestnik 56(1):83-104.

Mlakar A (2009). Negotovost v prostorskonačrtovalnih postopkih [Uncertainty in spatial planning procedures]. Urbani izziv 20(2):22-35.

Pampulha ME, Oliveira A (2006). Impact of an herbicide combination of bromoxynil and prosulfuron on soil microorganisms. Current Microbiology 53:238-243.

Pavlovec R (1966). Paleogene strata in Goriška brda (Western Yugoslavia). Bulletin scientifique 11(10-12):243-244.

Perko D, Orožen Adamič M (Eds) (1998). Slovenija - pokrajine in ljudje [Slovenia-landscapes and people].Ljubljana: Mladinskaknjiga.

Podveršič B (1999). Izvor in oblike kolonata v Brdih [The source and shape of the colonate in Brda] In: Stres P (Ed). Briški zbornik. Občina Brda, Dobrovo.

Pontius RG, Gao Y, Giner NM, Kohyama T, Osaki M, Hirose K (2013). Design and interpretation of intensity analysis illustrated by land change in Central Kalimantan, Indonesia. Open Access Journal Land 2:351369.

Pontius RG, Shusas E, McEachern M (2004). Detecting important categorical land changes while accounting for persistence. Agriculture, Ecosystems \& Environment 101(2-3):251-268.

Prosdocimi M, Cerdà A, Tarolli P (2016). Soil water erosion on Mediterranean vineyards: A review. Catena 141:1-21.

$\mathrm{RCH}$ (2017). Register of Cultural Heritage. Ministry of Culture of the Republic of Slovenia. Database of the Archives of the Republic of Slovenia. Retrieved 2017 Apr 7 from http://giskd6s.situla.org/giskd/.

Reidsma P, Tekelenburg T, Van den Berg M, Alkemade R (2006). Impacts of land-use change on biodiversity: An assessment of agricultural biodiversity in the European Union. Agriculture Ecosystems \& Environment 114(1):86-102.

Ribereau-Gayon P, Dubourdieu D, Doneche B, Lonvaud A (2006). Handbook of enology, Vol 1: The microbiology of wine and vinifications, Second Edition. West Sussex, England: John Wiley and Sons Ltd.

Rikanovič R (2003). Digitalne podatkovne zbirke pokrovnosti/rabe tal Slovenije [Digital land cover/use databases of Slovenia]. Geologija 47(2):283-290.

Rodrigo Comino J, Iserloh T, Morvan X, Issa OM, Naisse C, Keesstra SD, ... Ries JB (2016). Soil erosion processes in European Vineyards: A qualitative comparison of rainfall simulation measurements in Germany,Spain and France. Hydrology3(1):6.
Sayer J, Sunderland T, Ghazoul J, Pfund JL, Sheil D, Meijaard E, ... Buck LE (2013). Ten principles for a landscape approach to reconciling agriculture, conservation, and other competing land uses. Proceedings of the National Academy of Sciences of the United States of America 110(21):8349-8356.

Sastre B, Barbero-Sierra C, Bienes R, Marques MJ, García-Díaz A (2016). Soil loss in an olive grove in Central Spain under cover crops and tillage treatments, and farmer perceptions. Journal of Soils and Sediments 17(3):873-888.

Šmid Hribar M, Geršič M, Pipan P, Repolusk P, Tiran J, Topole M, Ciglič R (2017). Cultivated terraces in Slovenian landscapes. Acta Geographica Slovenica 57(2):83-97.

SMRS (2015). The Surveying and Mapping Authority of the Republic of Slovenia. Ministry of the Environment and spatial planning. Data on administrative services. Retrieved 2017 May 2 from http://www.gu.gov.si/en/services/podatki_gu/\#c12821.

SORS (2016). Statistical Office of the Republic of Slovenia. SI-Stat Data Portal. Retrieved 2016 Apr 20 from http://pxweb.statsi/pxwe b/dialog/statfilel.asp.

Stoate C, Boatman ND, Borralho RJ, Carvalho CR, de Snoo GR, Eden P (2001). Ecological impacts of arable intensification in Europe. Journal of Environmental Management 63(4):337-365.

Štabuc R, Hauptman S, Škvarč A, Brdnik M, Maljevič J, Novak E, Vršič S (2007). Slovenske trte in vina v Evropski uniji, [Slovenien vines and wines in the European Union]. Zbornik referatov 3. slovenskega vinogradniško-vinarskega kongresa, Maribor.

Turner BL, Lambin EF, Reenberg A (2007). Land change science special feature: The emergence of land change science for global environmental change and sustainability. Proceedings of the National Academy of Science of the United States of America 104(52):20666-20671.

Zorn M, Komac B (2009). The importance of landsliding in a flysch geomorphic system: The example of the Goriška Brda Hills (W Slovenia).Zeitschrift für Geomorphologie 53(2):57-78.

Verheye W H (2009). Land Use, Land Cover and Soil Sciences. In: Land use planning. Oxford, EOLSSPublishers Company Limited. 